\title{
Ultrastructural Aspects of Spermatogenesis in Phalloceros caudimaculatus (Teleostei, Poeciliidae)
}

\author{
Aspectos Ultraestructurales de la Espermatogénesis \\ en Phalloceros caudimaculatus (Teleostei, Poeciliidae)
}

\author{
Carlos Alberto Vicentini; Mario Esteban Muñoz \& Irene Bastos Franceschini Vicentini
}

\begin{abstract}
VICENTINI, C. A.; MUÑOZ, M. E. \& VICENTINI, I. B. F. Ultrastructural aspects of spermatogenesis in Phalloceros caudimaculatus (Teleostei, Poeciliidae). Int. J. Morphol., 28(3):951-956, 2010.

SUMMARY: The aim of the present study was to analyze the ultrastructural aspects of spermatogenesis in Phalloceros caudimaculatus, during cell proliferation. The parenchyma is organized morphologically as lobular restricted spermatogonial testis. Spermiogenesis in this species is characterized by four morphological stages of development (spermatids S1 through S4). The mature spermatids and spermatozoa heads are situated at the periphery of the cyst surrounded by the cytoplasm of the Sertoli cells. The germ cell's ultrastructure and spermatogenesis in P. caudimaculatus are very similar to that of other poeciliids.
\end{abstract}

KEY WORDS: Spermatogenesis; Ultrastructure; Poeciliidae; Phalloceros caudimaculatus.

\section{INTRODUCTION}

Phalloceros caudimaculatus (Cyprinodontiformes, Poeciliidae), popularly called "Guaru" (Machado et al., 2002) is a species of fresh-water fish that thrive along the entire Brazilian coast. P. caudimaculatus is mainly distributed throughout the states of Rio Grande do Sul, Rio de Janeiro, Espírito Santo, Bahia and São Paulo (Wolff et al., 2007). Additionally, based on studies of biogeographical distribution of poeciliid performed by Hrbek et al. (2007), the genus Phalloceros is mainly distributed in the Southern portion of South America.

Studies concerning the reproductive cycle of Poeciliidae, emphasizing the spermatogenesis, were performed by Fraile et al. (1992) and Koya \& Iwase (2004), featuring the structure of the Gambusia affinis restricted spermatogonial type testis. Fraile et al. observed that the reproductive cycle of $G$. affinis comprises two distinct periods: spermatogenesis, with cell proliferation and an increase in the gonadosomatic index, and testicular quiescence, characterized by the absence of cell proliferation and decreased testicular volume.

Regarding the organization and testicular spermatogenesis in teleosts, Grier \& Uribe-Aranzábal (2009) described three distinct testicular types: anastomosing tubular testis, lobular restricted spermatogonial testis and lobular unrestricted spermatogonial testis. In the anastomosing tubular testis the germinal compartment and tubules form loops that are interconnected, from the periphery to the testicular duct region (Grier, 1993; Grier \& UribeAranzábal). In the lobular restricted spermatogonial testis the spermatogonia are confined in the distal lobes in the testicular periphery. However, in the lobular unrestricted spermatogonial testis the spermatogonia are distributed along the entire length of the testicular lobules (Parenti \& Grier, 2004, Grier \& Uribe-Aranzábal).

In this study, we analyzed the morphological and ultrastructural aspects of testicular spermatogenesis of $P$. caudimaculatus during the cell proliferation period.

\section{MATERIAL AND METHOD}

Fifty adult specimens of Phalloceros caudimaculatus (Hensel, 1868), were collected during the summer (November 2002 to March 2003), in the Tiete river basin, 
municipality of Botucatu, São Paulo, Brazil. These animals were killed with an overdose of $0.01 \%$ benzocaine $(1 \mathrm{~g}$ of benzocaine in $10 \mathrm{~L}$ of $0.10 \%$ ethanol) and subsequently used for the following morphological studies.

Light microscopy. Samples of testes were fixed in Bouin's solution, embedded in paraplast (Oxford Labware, USA), sectioned at $5 \mu \mathrm{m}$, stained with haematoxylin-eosin, analyzed and documented with an Olympus BX50 light microscope (Olympus, Japan).

Electron microscopy. For transmission electron microscopy, testes tissue fragments were fixed for $4 \mathrm{~h}$ at $4^{\circ} \mathrm{C}$ in a $4 \%$ paraformaldehyde and $2 \%$ glutaraldehyde solution in $0.1 \mathrm{M}$ sodium cacodylate buffer, and postfixated for $2 \mathrm{~h}$ at $4^{\circ} \mathrm{C}$ in $1 \%$ osmium tetroxide $(\mathrm{pH}$ 7.4). The fragments were dehydrated in acetone and embedded in Araldite resin (Durcupan ACM, Fluka, Sigma Aldrich, St. Louis, MO, USA). Resin polymerization was then completed in an oven at $60^{\circ} \mathrm{C}$ for $48 \mathrm{~h}$. Ultrathin sections ( 60 and $80 \mathrm{~nm}$ ) were cut and transported to copper grids, contrasted with uranyl acetate and lead citrate, analyzed and then documented photographically with a Philips CM100 transmission electron microscope (Eindhoven, Netherlands). For scanning electron microscopy (SEM), the testes were: fixed in $2.5 \%$ glutaraldehyde, dehydrated in acetone, dried using the critical point method, gold sputter coated, and observed with a 515 Philips SEM, at the Electron Microscopy Center of the Institute of Biosciences of Botucatu, UNESP, Brazil.

\section{RESULTS}

The adult male $P$. caudimaculatus has a pair of fused ovoid testes located along the middle line of the body (Fig. 1A). The testicular parenchyma is organized morphologically as lobular restricted spermatogonial testis. The germinal epithelium contained germ cells cysts bordered by Sertoli cells, (Figs. 1B and 1C). The germ cells within each cyst undergo synchronous development. The spermatogonia are arranged separately, thus being characterized as primary spermatogonia, or in groups, in this case forming cysts of secondary spermatogonia (Fig. 1C). Cysts of primary spermatocytes can be identified by the meiotic stages of their nuclei, with the formation of chromatin clumps and synaptonemal complexes (Figs. 1B and 1D). However, secondary spermatocytes are difficult to identify.

Spermiogenesis in P. caudimaculatus is characterized by four morphological stages of development (S1 through S4), based on the compaction and elongation of the nucleus (Fig. 1, E-I and Fig. 2, A-F). The spermatids in S1 presented a round nucleus with irregularly condensed chromatin (Fig. 1, E-F). In spermatids in S2 the nucleus became horseshoeshaped with dark chromatin located on the periphery. During this stage, the base of the nucleus was invaginated by a deep implantation fossa (Fig. 1, G-I). The flagellum exhibited the classical axoneme structure consisting of nine peripheral microtubule doublets surrounding a central pair of microtubule doublets $(9+2)$. The spermatids in $\mathrm{S} 3$ exhibited nuclei presenting an arrowhead shape, and spermatids in S4 exhibited nuclei which were elongated further (Fig. 2, A$\mathrm{H})$. The mature spermatids (S4), and spermatozoa heads were situated at the periphery of the cyst, surrounded by the cytoplasm of the Sertoli cells (Fig. 2, H-I).

The Sertoli cells in P. caudimaculatus had an oval or irregularly shaped nucleus and presented few organelles such as mitochondria and cytoplasmic residual bodies. These cells had cell-cell adhesive junctions constituted of adherens junctions and desmosomes (Fig. 2, G-I). At the end of spermiogenesis, these adhesive junctions between the Sertoli cells is broken, opening the cysts, and allowing groups of spermatozoa, called spermatozeugmata, to be released into the efferent ducts (Fig. 1B).

\section{DISCUSSION}

The testicular structure of $P$. caudimaculatus is similar to that reported in other poeciliid teleosts such as Poecilia reticulata (Billard, 1984), Poecilia latipinna (Grier et al.,1980), and Gambusia affinis holbrooki (Fraile et al., 1992). The testicular parenchyma of $P$. caudimaculatus is of the lobular restricted spermatogonial type as described for derived teleosts, which includes atherinomorphs (Parenti \& Grier; Grier \& Uribe-Aranzábal).

In $P$. caudimaculatus, the cytoplasmic extensions of the Sertoli cells form spermatogenetic cysts that envelope a single spermatogonium or a group of germ cells. According to Pudney (1995), in Atherinomorpha primary spermatogonia occurs at the blind end of the lobule and undergoes several mitotic divisions before becoming associated with Sertoli cells to form cysts. As cysts mature they move down the lobule towards the efferent sperm ducts.

The testis of $P$. caudimaculatus during the summer (November 2002 to March 2003) exhibited cellular proliferation, with all phases of germ cell development present. However, the duration of the spermatogenesis and the degree of testicular enlargement in atheriniform teleost varied with the species and geographic location (Fraile et al.). 


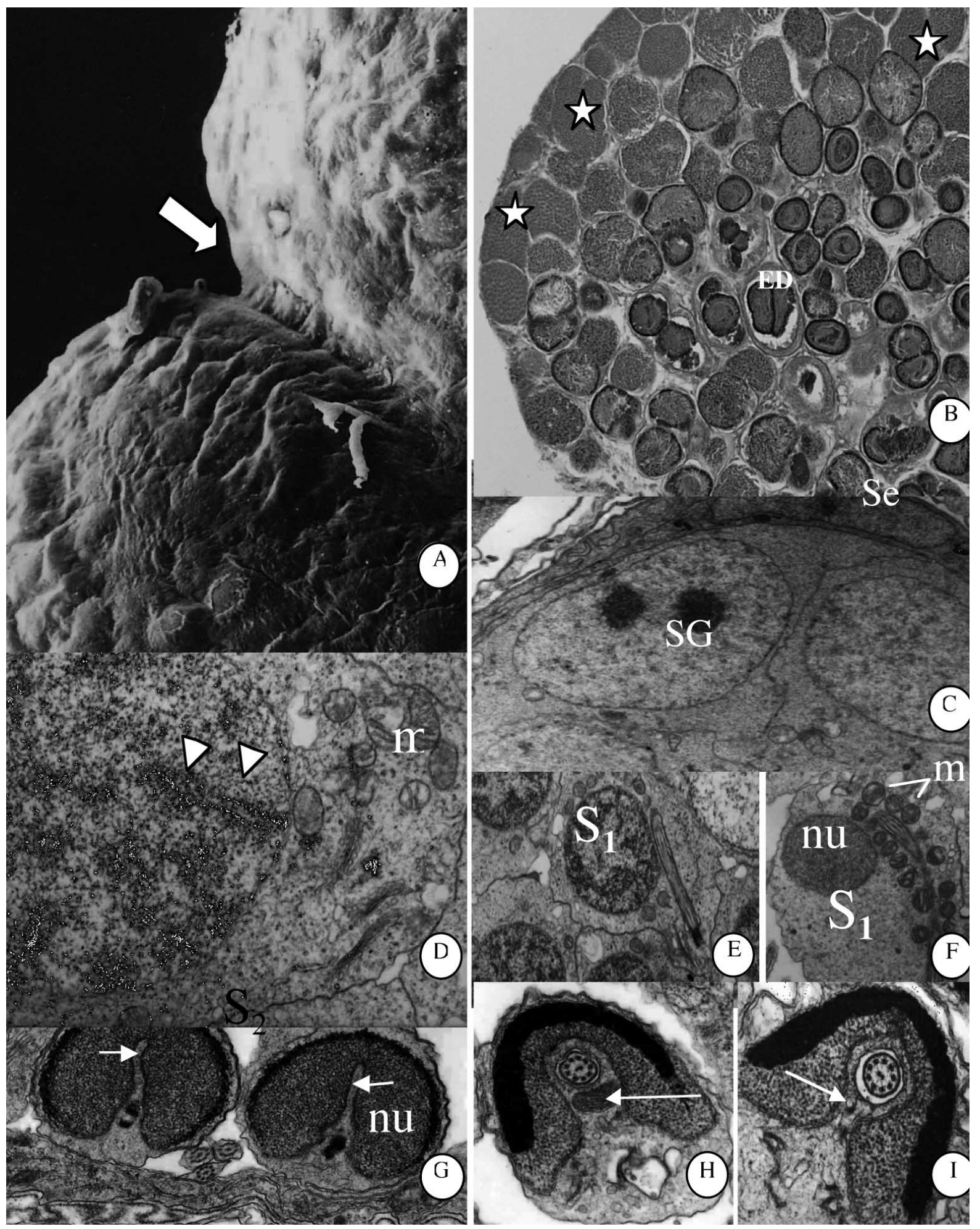

Fig. 1. A- Scanning electron microscopy of the testicular fusion in Phalloceros caudimaculatus (arrow), (105X). B- Light micrograph of testis revealing numerous cysts in various stages of development (stars) and the spermatozeugmata in the efferent ducts (ED), (200X). C- Ultrastructure of the secondary spermatogonia (SG) surrounded by Sertoli cell (Se), (10000X). D- Primary spermatocyte: note the synaptinemal complex (arrowhead) and mitochondrias (m), (21000X). Cyst of spermatids S1 (E - F), nucleus (nu) and mitochondrias (m), (16500X and 21000X). Spermatids S2 (G - I) showing a horseshoe-shaped nucleus (nu), and nuclear fossa (arrows), (45000X and 65000X). 

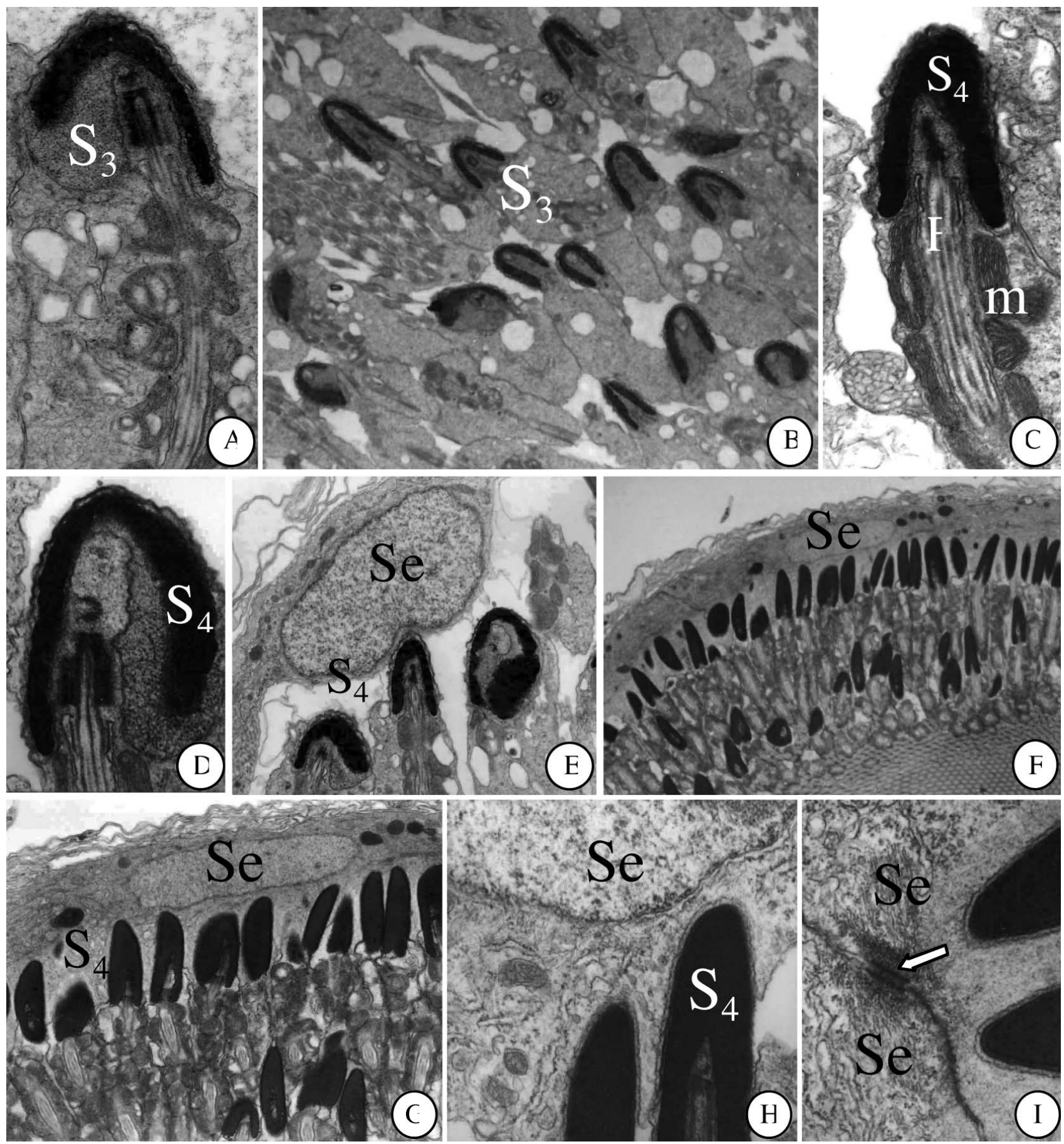

Fig. 2. A - B, Spermatids S3 with nucleus presenting an arrowhead shape (21000X and 6500X). C - D, Spermatid S4 showing elongated nucleus, note the flagellum (f), and mitochondrias (m), (27500X and 50000X). E - H, Cysts of the spermatids S4; note spermatids heads situated at the periphery of the cysts, surrounded by the cytoplasm of the Sertoli cells ( $\mathrm{Se}),(\mathrm{E}=16500 \mathrm{X}, \mathrm{F}=5000 \mathrm{X}, \mathrm{G}=13000 \mathrm{X}, \mathrm{H}=50000 \mathrm{X})$. I - The adherens junction (arrow) between the Sertoli cells $(\mathrm{Se}),(50000 \mathrm{X})$.

The germ cell ultrastructure and spermatogenesis in P. caudimaculatus are very similar to that of other poeciliids. The spermiogenesis process was characterized by four morphological stages of development (spermatids S1 through S4), as reported for Gambusia affinis holbrooki. In this species the primary spermatogonia and spermatozoa ( $\mathrm{S} 4$ cells 
and spermatozeugmata) were observed throughout the entire year (Fraile et al.). This finding has also been reported in Fundulus heteroclitus (Matthews, 1938).

In $P$. caudimaculatus the spermatozoa heads are situated at the periphery of the cyst, surrounded by the cytoplasm of Sertoli cells, as reported for Poeciliidae (Grier et al., 1978; Grier, 1981; Fraile et al.; Pudney; Grier et al., 2005; Grier \& Uribe-Aranzábal). According to Grier \& Uribe-Aranzábal sperm are bundled as spermatozeugmata and observed in the testis ducts of the viviparous species of atherinomorphs, Xenotoca eiseni (Goodeidae) and Poecilia latipinna (Poeciliidae). The sperm flagella course over the surface of spermatozeugmata in the species of Goodeidae, while sperm nuclei form the surface of spermatozeugmata in species of Poeciliidae (Grier et al., 1978; Grier, 1981; Grier et al., 2005).

\section{ACKNOWLEDGEMENTS}

This work is supported by grants from Fundação de Amparo à Pesquisa do Estado de São Paulo - FAPESP (n ${ }^{\circ}$ 97/2812-8), Conselho Nacional de Desenvolvimento Científico e Tecnológico - CNPq (n 300693/91-5), and Fundação para o Desenvolvimento da UNESP, FUNDUNESP, Brazil.

VICENTINI, C. A.; MUÑOZ, M. E. \& VICENTINI, I. B. F. Aspectos ultraestructurales de la espermatogénesis en Phalloceros caudimaculatus (Teleostei, Poeciliidae). Int. J. Morphol., 28(3):951-956, 2010.

RESUMEN: El objetivo del presente estudio fue analizar los aspectos ultraestructurales de la espermatogénesis en Phalloceros caudimaculatus, durante el periodo de proliferación celular. El parénquima testicular está morfológicamente organizado como lobular espermatogonial restricto. La espermiogénesis en esta especie se caracteriza por cuatro etapas morfológicas de desarrollo (espermátidas S1 hasta S4). Las cabezas de las espermátidas maduras y espermatozoides están situadas en la periferia de los cistos, rodeados por el citoplasma de las células de Sertoli. La ultraestructura de las células germinativas y la espermatogénesis en $P$. caudimaculatus son muy similares a las de otros poecílideos.

PALABRAS CLAVE: Espermatogénesis; Ultraestructura; Poeciliidae; Phalloceros caudimaculatus.

\section{REFERENCES}

Billard, R. Ultrastructural changes in the spermatogonia and spermatocytes of Poecilia reticulata during spermatogenesis. Cell Tissue Res., 237:219-26, 1984.

Fraile, B.; Sáez, F.J.; Vicentini, C.A.; De Miguel, M. P. \& Paniagua, R. The testicular cycle of Gambusia affinis holbrooki ( Teleostei: Poeciliidae). J. Zool. Lond., 228:115-26, 1992.

Grier, H. J. Cellular organization of the testis and spermatogenesis in fishes. Am. Zool., 21:345-57, 1981.

Grier, H. J. Comparative organization of sertoli cells including the sertoli cells barrier. In: The sertoli cell. Russell, L. D. \& Griswald, M. D. (eds.). Clearwater, FL, Cache River Press, 1993. pp.704-39.

Grier, H. J.; Fitzsimons, J. M. \& Linton, J. R. Structure and ultrastructure of the testis and sperm formation in goodeid teleosts. J. Morphol., 156:419-38, 1978.

Grier, H. J.; Horner, J. \& Mahesh, V. B. The morphology of enclosed testicular tubules in a teleost fish, Poecilia latipinna. Trans. Amer. Micros. Soc., 99(3):268-76, 1980.

Grier, H. J. \& Uribe-Aranzábal, M. C. The testis and spermatogenesis in teleosts. In: Reproductive biology and phylogeny of fishes (Agnathans and Bony fishes). Jamieson, B. G. M. (ed.). Endfield, New Hampshire, Science Publishers, 2009. pp.119-42.

Grier, H. J.; Uribe, M. C.; Paretni, L. R. \& De la Rosa-Cruz, G. Fecundity, the germinal epithelium, and folliculogenesis in viviparous fishes. In: Uribe, M. C. \& Grier, H. J. (eds.). Viviparous fishes. Florida, New Life Publication Homestead, 2005. pp.191-226.

Hrbek, T.; Seckinger, J. \& Meyer, A. A phylogenetic and biogeographic perspective on the evolution of poeciliid fishes. Mol. Phylogenet. Evol., 43:986-98, 2007.

Koya, Y. \& Iwase, A. Annual reproductive cycle and rate of the spermatogenic process in male mosquitofish Gambusia affinis. Ichthyol. Res.,51:131-6, 2004. 
VICENTINI, C. A.; MUÑOZ, M. E. \& VICENTINI, I. B. F. Ultrastructural aspects of spermatogenesis in Phalloceros caudimaculatus (Teleostei, Poeciliidae). Int. J. Morphol., 28(3):951-956, 2010

Machado, G.; Giaretta, A. A. \& Facure, K. G. Reproductive Cycle of a Population of the Guaru, Phallocerus caudimaculatus (Poeciliidae), in Southeastern Brazil. Stud. Neotrop. Fauna Environ., 37(1):15-8, 2002.

Matthews, S. A. The seasonal cycle in the gonads of Fundulus. Biol. Bull. mar. biol. Lab. Woods Hole, 75:6674, 1938.

Parenti, L. R. \& Grier, H. J. Evolution and phylogeny of gonad morphology in bony fishes. Integr. Comp. Biol., 44:333-48, 2004.

Pudney, J. Spermatogenesis in nonmammalian vertebrates. Microsc. Res. Tech., 32:459-97, 1995.

Wolff, L. L.; Hreciuk, E. R.; Viana, D.; Zaleski, T. \& Donatti, L. Population structure of Phalloceros caudimaculatus (Hensel, 1868) (Cyprinodontiformes, Poeciliidae) collected in a brook in Guarapuava, PR. Braz. Arch. Biol. Tech., 50(3):417-23, 2007.
Correspondence to: Dr. Carlos Alberto Vicentini Departamento de Ciências Biológicas, FC, UNESP. Avenida Luiz Edmundo Carrijo Coube, 14-01, CEP: 17.033-360, BAURU, SP BRASIL

Email: carlosav@fc.unesp.br

Received: 23-06-2010

Accepted: 17-07-2010 